\section{Attendance Allowance}

As from 6 December the new tax-free "attendance allowance" of $£ 4.80$ a week may be claimed by certain severely disabled persons living at home and by parents with severely disabled children. It will be paid in the cases of children aged from 2 to 16 and those above that age (there is no upper age limit) who are either (1) so severely disabled physically or mentally that they require from another person, in connexion with their bodily functions, frequent attention throughout the day and prolonged or repeated attention during the night; or (2) so severely disabled physically or mentally that they require continual supervision from another person in order to avoid substantial danger to themselves or others. One of these conditions must be satisfied for a period of at least six months before the allowance can be received, but the whole or part of the period can be before 6 December or, in the case of children, before the child is 2 years old. For disabled children to qualify the attention and supervision they require must be substantially above that normally needed by a child of the same age and sex.

These conditions are important, since patients who have been encouraged to apply for the allowance may think it is merely a matter of asking their doctor to "order" it. An attendance allowance board will decide whether the medical requirements are satisfied. In many cases a medical report will be needed, for which a fee will be paid. Lord Amulree, chairman of the Attendance Allowance Board, wrote to all general practitioners about the scheme in June. Two leaflets, ${ }^{12}$ one applicable to children and the other to adults and obtainable from local offices of the Department of Social Security, explain the allowance and how it may be applied for.

Another aspect of the matter is supplying the appropriate help that the disabled need. Since this is largely a matter of nursing it is right that it should be organized through the medical officer of health and his nursing services and not as a separate service under the new social service departments. No doubt medical officers of health will find the help of their general-practitioner colleagues invaluable in trying to find persons willing to act as sitters-in and general helpers. This is a community medicine exercise which is to be welcomed as offering an excellent opportunity for cooperation between family doctors and medical officers of health as well as bringing succour to persons sorely in need of it. Doctors can also do much for their patients in guiding them on how to apply for the allowance and in advising them on how best to use it.

\footnotetext{
Attendance Allowance for Adults, Leaflet NI 181, 1971. Department of Health and Social Security.

2 Attendance Allowance for Children, Leaflet NI 182, 1971. Department
} of Health and Social Security.

\section{Herpesvirus Ubique}

The EB virus, named after M. A. Epstein and Y. M. Barr, was first discovered in association with lymphoblasts derived from Burkitt lymphoma and growing in culture. ${ }^{1}$ Patients with this tumour were then generally found to have high titres of antibody to antigens of the virus and to cell mem- brane antigen. ${ }^{2}$ These results led to an examination of other tumours and of cell cultures derived from them for identical, or similar, viruses and a search for antibodies in other kinds of sera. It soon became apparent that lymphoblast cell lines from apparently normal persons, when maintained in culture, also produced a herpes-like virus. ${ }^{3}$ And sera from the donors of the lymphoblasts and other normal persons were found to contain antibodies, usually lower in titre but otherwise similar, to those found in the patients with lymphoma.

A laboratory accident showed the probable reason for these findings. Young adults who were initially seronegative developed infectious mononucleosis and antibodies after contact with the virus. ${ }^{4}$ Cultures of peripheral lymphocytes from patients with this disease consistently gave rise to lymphoblast cell lines, and in them the virus was replicated. Rarely, if at all, could cell lines be produced from uninfected donors. ${ }^{5}$ This herpesvirus replicates, then, in cells of the lymphoreticular system, and apparently only in such cells, and cell lines can be established only if the virus is present. ${ }^{5}$ Moreover, fetal tissues were always found not to harbour the virus, so it is not congenitally transmitted. ${ }^{6}$

Only a small proportion of the normal persons had had clinical infectious mononucleosis, but in the first 10 years of life infection with this virus is not easily recognizable. The incidence of this disease in young adults is about 50 per 100,000 population in developed countries, but it rises to $300-1,500$ per 100,000 in colleges in the United States. Strangely, perhaps, unusually high titres of antibody to this virus were not found in patients with leukaemia or Hodgkin's disease. $^{7}$

The virus may have a causal role in infectious mononucleosis but a casual one in Burkitt's lymphoma. Since both are diseases of the lymphoreticular system this is not unlikely. But the part played by this or a very similar virus in nasopharyngeal carcinoma is harder to understand, for these tumours comprise a variety of histological types from lymphoepitheliomatous carcinoma (tumour cells in a dense lymphoid stroma) to squamous cell carcinoma. Recently J. M. Goldman and his colleagues ${ }^{8}$ found that antibody levels to EB virus in 21 patients with nasopharyngeal carcinoma were unrelated to the type of tumour but were significantly higher than in a group of 140 controls, confirming in this respect the findings of others.9 Attempts to establish in-vitro cultures of these tumours were successful in six cases, but no lymphoblastoid transformation occurred (as in de Thé and colleagues' study $\left.{ }^{10}\right)$, and no herpes-like virus could be seen. Herpes virus (type 2) has also been found in association with carcinoma of the uterine cervix. ${ }^{11}$.

The relationship of EB virus to Burkitt's lymphoma will be investigated by a group sponsored by the International Agency for Research in Cancer. They intend to collect sera from a population of some 35,000 children between birth and 5 years of age in the West Nile district of Uganda. ${ }^{12}$ Some 30 new cases of the disease are expected to occur over the five-year period of the investigation. The sera from such cases, and suitable controls, will be titrated for antibody to EB virus in the expectation that, if this virus is the cause of the disease, seroconversion from negative to positive will precede the emergence of the tumour-as, indeed, occurs for EB virus and infectious mononucleosis. But this investigation is unlikely to be so simple as it sounds, for these children will doubtless be found to have other diseases, such as malaria, while they are under observation, and for these they must receive treatment.

Clearly the role of the herpes virus group in oncogenesis requires further investigation. EB virus and the virus associ- 
ated with infectious mononucleosis are serologically related but they are not necessarily identical. ${ }^{13}$ The virus associated with nasopharyngeal carcinoma also cross-reacts with EB virus. The simplest hypothesis at present is that these viruses are co-carcinogens and infection with them ensures a multiplication of cells which may be self-limited (as for infectious mononucleosis) or unrestricted (as for Burkitt's lymphoma or nasopharyngeal carcinoma), the course depending on other events in the history of the cells.

1 Epstein, M. A., Achong, B. G., and Barr, Y. M., Lancet, 1964, 1, 702. 2 Henle, G., et al., Fournal of the National Cancer Institute, 1969, 43, 1147. 3 Gerber, P., and Monroe, J. H., Fournal of the National Cancer Institute, 1968, 40, 855 .

${ }^{4}$ Henle, G., Henle, W., and Diehl, V., Proceedings of the National Academy of Sciences, U.S.A., 1968, 59, 94 .

${ }^{5}$ Henle, W., and Henle, G., in Oncogenesis and Herpes-type Viruses. Conference at Christ's College, Cambridge, 20-25 June 1971.
.

6 Nilsson, K., Klein, G., Henle, G., and Henle, W., in Oncogenesis and

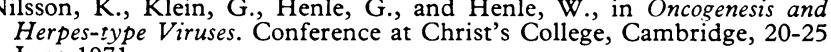
June 1971 .

7 Goldman, J. M., and Aisenberg, A. C., Cancer, 1970, 26, 327.

Goldman, J. M., Goldman, M. L., and Milier, D., fournal of the American Medical Association, 1971, 216, 1618.

${ }^{9}$ Schryver, A. de, et al., Clinical and Experimental Immunology, 1969, $5,443$.

10 Thé, G. de, Ambrosioni, J. C., Ho, H. C., and Kwan, H. C., Nature, $1969,221,770$.

11 British Medical fournal, 1970, 4, 256.

12 Thé, G. de, in Oncogenesis and Herpes-type Viruses. Conference at Christ's College, Cambridge, 20-25 June 1971 .

${ }^{13}$ Niederman, J. C., McCollum, R. W., Henle, G., and Henle, W., fournal of the American Medical Association, 1968, 203, 205.

\section{Psychiatric Care at Nottingham}

The case register, a method of recording all patients who have contacted psychiatric services of any sort in a particular locality, is increasing in popularity. The most recent of a lengthening line of analyses of such registers emanates from Nottingham. ${ }^{1}$ It follows hard on the heels of a report on psych:atric hospitals and units in England and Wales, ${ }^{2}{ }^{3}$ and in many ways the two are complementary, the one being a study in depth and the other in breadth of comparable data.

Mapperley Hospital, Nottingham, with whose catchment area the register is concerned, enjoys an honoured place in the recent history of psychiatry in Britain. This distinction is due in no small measure to the genius of the late Dr. Duncan Macmillan, who until his retirement in 1966 was its physician superintendent, and it is fitting that the report is dedicated to his memory. Dr. Macmillan's unique contribution was the integration, initiated in 1945 , of the mental health service with the public health department so that the facilities of each became available to both on a "joint user" basis. $\mathrm{He}$ was the medical officer for mental health and acted as adviser to the medical officer of health of the city, who was in turn a member of the management committee of Mapperley. With this degree of high-level co-operation it is not surprising that community facilities for the care of psychiatric cases could be developed, so enabling a certain reality to be infused into the concept of community care. Nottingham, alas, is not typical of the country as a whole, though, to be fair, there may be demographic factors which operate in its favour.

The Nottingham register reflects and indeed highlights most of the trends reported on a national basis. Thus, per 1,000 population in the area the number of inpatients at the end of 1969 had fallen to 1.58. The range for mental hospitals in England and Wales in that year was from 1.2 to 4.5 , and Mapperley fell into the lowest one-fifth of that range. Conversely, there was a greater use of other services at Nottingham. Outpatient attendances, day-hospital attendances, home visits by doctors, and contacts with social workers in the psychiatric field all rose substantially, promoting Mapperley well into the First Division on all these counts. The number of admissions in relation to population rose by a modest $43 \%$-modest, that is, compared with a national increase of $150 \%$ between 1959 and 1969. Again, like national trends, the numbers of patients contacting the service rose with age up to 25 , then remained steady until a decline to the age of 64 , and then rose-particularly sharply at the age of 75 and over. The spectre of the aged, mindless body hangs over the calculations of the planners there as elsewhere in the country.

Over the years the number of patients in contact with all psychiatric services increased by about one-third, lending substance to the thesis that the greater the facilities provided the more patients will avail themselves of them. Parkinson's law is universally applicable, it would appear.

A six-year follow-up of new contacts in 1962-8 is analysed. The most important finding is that in this period $40 \%$ of males and $43 \%$ of females went into hospital. If these statistics are considered in conjunction with the reported rise of $43 \%$ in the number of admissions it could be that, despite the fall in the number of beds in use, the actual volume of work undertaken by the parent mental hospital has increased.

${ }^{1}$ Department of Health and Social Security, Statistical Report Series No. 13: The Nottingham Psychiatric Case Register Findings 1962 to 1969. London, H.M.S.O., 1971 ( $65 \mathrm{p} \mathrm{net).}$

2 Department of Health and Social Security, Statistical Report Series No. 12. $P$ sychiatric Hospitals and Units in England and $W$ ales. London, H.M.S.O., 1971 .

${ }^{3}$ British Medical fournal, 1971, 4, 249.

\section{More Money for Health}

More money for health makes good political copy. So the Government adroitly announced some proposed increases in health services financel a day or so before setting these into the broader context of future Government spending, outlined in a White Paper $^{2}$ last week (see p. 634). The extra $£ 118$ m. - spread over the next four years at 1971 pricesfor health and personal social services is over and above the growth planned in last year's expenditure review, ${ }^{3}$ which has been appropriately revised for the latest review. ${ }^{2}$

Economic refinements applied to the estimates allow for reasonably valid comparisons between the years under review. The Government intends to raise spending on health between now and 1976 by just over $£ 400 \mathrm{~m}$. to $£ 2,834 \mathrm{~m}$., thus increasing health's share of central government spending for specific programmes by just over $1 \%$ to around $12.5 \%$. By 1976 health spending will have passed defence and only education at $£ 3,261 \mathrm{~m}$. and social security at $£ 4,700 \mathrm{~m}$. will have a larger slice of the budget, which will have risen to $£ 22,694 \mathrm{~m}$., the Chancellor estimates.

A table giving a breakdown of the health budget forecasts until 1976 is at p. 634. Making a tour through these estimates stretching four years ahead in an inflationary era can be confusing, particularly when the responsibility for some services are changing. So it is helpful that Sir Keith Joseph has specified the services which will benefit from his promised bonus, some of which is to go towards the cost of reorganizing the N.H.S. Few doctors will disagree with his priorities for the elderly and mentally ill. The public will 